\title{
Neoproterozoic magmatism in Liansandao area, north of the Sulu orogen (China) and its geological implication: Evidence from zircon $\mathrm{U}-\mathrm{Pb}$ dating and $\mathrm{Hf}$ isotopes
}

\author{
SONG ZHAO-JUN ${ }^{1}$, YUAN XING-YU ${ }^{1}$, MENG FAN-XUE ${ }^{1}$
}

${ }^{1}$ Shandong University of Science and Technology, Qingdao 266590, China

The Neoproterozoic period is a very active stage of global tectonic-magmatic activities, and it is an important period during the Earth's evolution. In fact, the assembly and breakup of Rodinia supercontinent were the responses to the tectonic activities during this period. The magmatic activities during the Neoproterozoic period were also widely distributed in the Yangtze Block. The formation time and tectonic setting are unclear due to the absence of systematic chronology and geochemical research. The study area, i.e., Sulu orogen, was generally considered as the eastern extension of the Qinling-Dabie orogen, and it was an ideal natural laboratory to understand the petrological and geochemical changes during the deep subduction of the continent. In this study, zircon U-Pb ages and $\mathrm{Hf}$ isotope of granitic gneiss from the Liansandao area, Sulu orogen, were presented. Three granitic gneiss samples give the weighted average ages of $747 \pm 12 \mathrm{Ma}(\mathrm{MSWD}=0.91, \mathrm{n}=13$ ), $767 \pm 12 \mathrm{Ma}$ $(\mathrm{MSWD}=5.4, \mathrm{n}=19)$, and $765 \pm 21 \mathrm{Ma}(\mathrm{MSWD}=1.7, \mathrm{n}=14)$, respectively, indicating that the formation age is Neoproterozoic. The corresponding $\varepsilon_{H}(\mathrm{t})$ values of the three samples were -7.2 -10.5, -6.0 -17.5, and -6.8 -12.0, respectively. Zircons with negative $\varepsilon_{\mathrm{Hf}}(\mathrm{t})$ values indicated the recycling of continental crustal materials. And the widely variations in $\mathrm{Hf}$ isotopes give evidence to the mixing of mantle-derived material. Combined with the Hf model age, the protolith of the granitic gneiss in Liansandao area might be the result of re-melting of Paleoproterozoic continental crust at $\sim 750 \mathrm{Ma}$, which is a response to the break-up of Rodinia supercontinent, i.e., the mantle-derived magma formed in extensional settings upwelled and underplated to the lower-crust, which subsequently led to the melting of ancient continental crust, and then mixing between mantlederived and crust-derived magma produced the granitic protolith in the study area.

Acknowledgement: The current study is supported by the National Natural Science Foundation of China (NSFC) (41472155). 